\title{
PROBLEMS OF FINNISH EXTREME RIGHT-WING ORGANISATIONS OF FINLAND'S FIRST REPUBLIC
}

The article is devoted to the very difficult task of identifying, archiving and organising disparate and, for the most part, incomplete archives of Finnish extreme nationalist movements of the interwar period and the Second World War, in the other words, in the First Republic of Finland (1919-1944). The most important of these organisations can be considered to be The Lapua Movement (1929-1932) and its successor, The Patriotic People's Movement (IKL) (1932-1944) and the Academic Karelia Society (1922-1944).

National questions, becoming quite important in the first half of the $20^{\text {th }}$ century, become in modern Finland all the more important in terms of their scientific research. Their study is already absolutely necessary for the full and complete understanding of the events in Finland of that period. In this connection it is quite revealing that in the first decades after the Second World War studying the history of the Finnish right nationalist radicalism rarely attracted researchers, as the political situation in the country did not allow an objective reconstruction of the history of the losing side. The situation was also affected by the inaccessibility of many archival documents. The history of the Finnish right nationalist radicalism of the interwar period is still not enough studied both in Russian and in Finnish and in world historiography.

Considering the problem of the history of right-wing nationalist movement in Finland it can be argued that, along with the importance of this research to explain the policy of 1920s-1930s Finland, as well as the problem of the country's participation in World War II on the side of Nazi Germany, there are still quite good prospects for the study proposed here. Moreover, it is possible to hope that the answers to urgent questions can mainly be found in the materials of the Finnish archives. Refs 31.

Keywords: Finland, Archives, The Academic Karelia Society, The Lapua Movement, The People's Patriotic Movement.

For citation: Vasara V.-T. Problems of Finnish extreme right-wing organisations of Finland's first republic. Vestnik of Saint Petersburg University. History, 2017, vol. 62, issue 2, pp. 345-357. DOI: 10.21638/11701/spbu02.2017.211

\section{B.-T. Bacapa}

\section{ПРОБЛЕМЫ ИСТОРИИ ПРАВОРАДИКАЛЬНЫХ ОРГАНИЗАЦИЙ ПЕРВОЙ РЕСПУБЛИКИ ФИНЛЯНДИИ}

В статье поставлена весьма нелегкая задача - исследовать по архивным материалам историю финских крайне правых националистических организаций межвоенного периода и периода Второй мировой войны, т. е. в Первой республике Финляндии (1919-1944 гг.). Главными из этих организаций можно считать так называемое лапуаское движение (1929-1932 гг.), оформившееся в партию Патриотическое народное движение (ИКЛ) (1932-1944 гг.), и Академическое карельское общество (1922-1944 гг.).

Национальные вопросы, крайне острые в первой половине XX в., в современной Финляндии приобретают все большую значимость с точки зрения их научного исследования, поскольку изучение финского правого националистического радикализма лежит в основе более полного и всестороннего понимания событий 1919-1944 гг. В первые послевоенные десятилетия эта тема практически не привлекала исследователей - прежде всего в силу внутренней политической ситуации, не позволявшей объективно представить историю проигравшей в войне стороны, сказывалась и недоступность многих архивных документов. В настоящее время

Vasara Viena-Tuuli - Researcher, 49, Kulmakatu, Tampere, 33500, Finland; viena-tuuli@skinsaw.com Васара Виена-Туули - исследователь, 33500, Финляндия, Тампере, Кулмакату, 49; viena-tuuli@ skinsaw.com

(c) Санкт-Петербургский государственный университет, 2017 
история финского правого националистического радикализма межвоенного времени остается по-прежнему малоизученной как в финской и российской, так и в мировой историографии.

Обращаясь к изучению истории финского праворадикального националистического движения, стоит отметить, что ее исследование важно не только для объяснения политики Финляндии 1920-1930-х годов и ее участия во Второй мировой войне на стороне нацистской Германии, но и в других аспектах, например для понимания внутриполитической обстановки в стране во второй половине 1940-х годов, и представляет собой перспективное направление научных разысканий. Не будет опрометчивым утверждать также, что ответы на назревшие вопросы исследователи найдут главным образом в материалах финляндских архивов. Библиогр. 31 назв.

Ключевые слова: Финляндия, архивы, Академическое карельское общество, лапуаское движение, Патриотическое народное движение.

National questions, becoming quite important in the first half of the $20^{\text {th }}$ century, become in modern Finland all the more important in terms of their scientific research. Their study is already absolutely necessary for the full and complete understanding of the events in Finland of that period. In this connection it is quite revealing that in the first decades after the Second World War studying the history of Finnish right nationalist radicalism rarely attracted researchers, as the political situation in the country did not allow the objective reconstruction of the history of the losing side. The situation was also affected by the inaccessibility of many archival documents. The history of the Finnish right nationalist radicalism of the interwar period is still not enough studied both in Russian and in Finnish and in world historiography.

The only serious work devoted to this subject in Finland was published in 1982, the book "The Finnish Extreme Right between the World Wars: Ideological Roots, Organisational Basis and Forms of Activity" [Nygård 1982]. In it the author Toivo Nygård brings to the fore the question of the ideological basis of the Finnish right-wing radicalism. The emphasis on ideology is justified, but the fact that the use of archival materials was limited made analysis of the practical activities of right-wing organisations difficult.

Besides T. Nygård, we must mention also the work of American professor Marvin Rintala [Rintala 1962], which is considered the source of the theory about the cause of the failure of right nationalist radicalism in Finland, defining its disagreement between generations directly within the extreme right-wing organisations. However, the idea that all Finnish supporters of anti-Bolshevik actions were members of the extreme right is doubtful. Rintala does not treat his sources critically enough, and in places analysis is simply absent.

Another aspect important in the quest to understand the features of institutionalisation of nationalist movements, is another study, "Greatness of Finland Was Our Aim: History of the Academic Karelia Society 1. Background, Organization, Ideas and Status in Society 1922-1939" [Eskelinen 2004], which is a large, serious scientific work devoted to little known aspects of the first pronounced right nationalist organisation in independent Finland, The Academic Karelian Society. Another very interesting work examining such issues is Risto Alapuro's "The Academic Karelia Society: Student Movement and People in the 1920's and 1930's" [Alapuro 1973]. It primarily examines the ideology and social structure of the Academic Karelia Society. This work is considered a classic of the Finnish social history. R. Alapuro comes to a very important conclusion that the Academic Karelia Society had features close to fascism. Curious is also the book "Hating All Russian: 
Elmo Kaila 1888-1935: Biography of an Activist, Grey Eminence of the Armed Forces and Chairman of the Academic Karelia Society" by Martti Ahti [Ahti 1999]. It is the only published biography of the chairman of the AKS Elmo E. Kaila. Besides Kaila's biography, the book studies the overall political situation in Finland in the early 1920's.

In this context, research of the former member of the organization Lauri Hyvämäki to some extent compensates for the existing historiographical lacunae, as it occurs he was one of the first Finnish researchers who engaged in a professional history of Finnish right-wing organisations [Hyvämäki 1971]. The researcher found the root cause of the nationalist Lapua Movement in the inefficiency of the government in the fight against communism. In addition, in his opinion, the disappointment of Right Forces political development in Finland since 1918 and the development of common European totalitarian ideas also influenced this movement. Hyvämäki adhered to the point of view of Marxist historians, according to which during the economic crisis of the late 1920's capitalists and employers via The Lapua Movement turned against the left wing labor movement.

On the other hand, the thesis by Juha Siltala "The Lapua Movement and the Kidnappings of 1930" [Siltala 2005] has already become a very in-depth study on the history of another quite significant right-wing nationalist organisation, the so-called Lapua Movement. Before the publication there were practically no studies describing in such detail the activities of the movement and it was not known more than at the time of its existence. Siltala's dissertation proves that the Lapua movement organised the kidnappings. Moreover, it is curious that the author defined the movement as an epilogue to the Civil war and the practical implementation of Finnish White Guard's policy.

The Lapua Movement found its place also in research on the history of Finnish leftwing forces. The researcher Juhani Paasivirta writes in his book "The Development of the Political Labor Movement in Finland" [Paasivirta 1949] that the Lapua Movement arose not only because of the revitalization of the Finnish communists, but above all because of the crisis of the Finnish parliamentary system. He said that the movement was influenced by Germany, where the people's right to act independently, outside the letter of the law was discussed actively. That is, remembering the old postulate: if you issue laws that are not enforced, the people have the right to perform their own truth.

In another book, devoted to the labor movement's history in Finland [Haataja et al. 1976], the authors, as well as Paasivirta, consider the occurrence of the Lapua Movement not only with the traditional left perspective. According to the view, which was established by the members of the right-wing nationalist movements, the Lapua Movement was a countermeasure to the threat from the East. The authors of this work see the role of the Civil Guards as especially influential. They believe that it was the lack of sufficient support of the Civil Guards that cramped a putsch in Mäntsälä to naught.

Among the more recent works, we note the thesis of R. Perälä "The Lapua Movement and the Power of the Word" [Perälä 1998], which deals with the origin and development of the public image of the Lapua Movement. The work is based on a survey of public opinion in the Finnish press. Since the real support of the movement was never tested in the elections, it was important to the movement how much power it represented in public opinion. Using materials of seventeen Finnish newspapers of different political views, Perälä gives the reader a complete picture of the "formation and decline" of the Lapua Movement, and which role the press played. 
Concluding the historiographical review, it should be noted that fewer studies have been conducted to the successor of the Lapua Movement, the party Patriotic People's Movement (IKL). There is only one good overview by the historian Mikko Uola - "The Blue-Black Brotherhood. The Patriotic People's Movement 1932-1944" [Uola 1982]. Although the work does not highlight enough issues such as the activities of the party during the war. In general, when it comes to studying the history of IKL, it is necessary to draw attention to the fact that, in principle, in the works related to the Lapua Movement, the activities of IKL are also affected as its direct successor.

However, in general we can say that the Finnish historians have never been able to make fully informed and objective conclusions of this page of history based on the historical sources. It therefore seems time for a new look that considers the shortcomings of our predecessors. It is already quite clear that the problem of further study of this topic is related to the need to attract new documentary sources. However, the well-known historian Vladimir Nikolaevich Baryshnikov has several studies in Russia partly compensating for this shortage [Baryshnikov 1997].

In addition, it is obvious that one of the main distinctive features of extreme nationalist sentiment in the Finnish society became, first of all, anti-Russian views, which actually formed in the environment of the right-wing movement in Finland of the 1920's, which was under the influence of the events of the First World and the Civil Wars, and where the "white" activists saw their main opponents in Russians. However, during the past near-century the internal and external situation of Finland has become different. The society continues to excite new and old questions related to national minorities, the position of the Swedish language in Finland, and the treatment of migrants, whose number in the country is increasing every year.

A very important feature of the study of nationalist sentiment in Finland of the interwar period is also the fact that the country clearly managed to overcome the threat to the democratic system by both the extreme left-wing and right-wing movements. However, at that time right nationalist trend in Finland continued to grow. In the interwar period, there were many organisations in Finland, which can be characterised as extreme right-wing, nationalist, anti-communist. This is evidenced by the list of the autumn of 1944 forbidden "pro-Hitler" organisations [Uola 1999, pp. 262-271]. Moreover, the Academic Karelia Society, the Lapua Movement and its successor - the party Patriotic People's Movement need to be analysed more seriously to understand the processes of Extreme Right activity. These organisations can be considered the most outstanding representatives of the Finnish right-wing nationalist movements and their activities demonstrate the versatility of this phenomenon in Finland, it also requires an appropriate analysis.

Moreover, it is obvious that the ideology, which was based on the extreme right-wing views, was expressed in two main prospects in Finnish nationalism. Firstly, it is "ryssäviha", i.e. hatred for everything Russian [Karemaa 1998; Vasara 2010], and secondly, it formed the ideology of the "Greater Finland" [Nygård 1978; Kirves, Näre 2014]. Both of these phenomena were expressed in different forms and at different historical periods, but it always remained important, describing the manifestations of nationalism in Finnish society of 1920s and 1930s.

On the other hand, it is important to bear in mind that in the activities of the Academic Karelia Society, the Lapua Movement and the party Patriotic People's Movement's some features had their substantial background in the earlier history of Finland. In ad- 
dition, especially important is the fact that, since the end of the $19^{\text {th }}$ century they were clearly manifested as a "white activism" [Hyvämäki 1971; Mainio 2015]. Therefore, first, the experience passed on to the next generation of "activists", and secondly, demonstrated the value of changes in ideology and form of their political activities in the early 1920's.

It has to be noticed that time dictated new requirements for the activities of politically active individuals. If the first period, "early activism", was dedicated to the fight against the tsar's power and russification in the beginning of $20^{\text {th }}$ century, the second period, the "new activism" began to unfold shortly after the outbreak of the First World War. Under the influence of this fear arose the "Jaeger Movement" and the militant nationalist organisation the "Civil Guard". The main goal of the activists of this period was Finland's withdrawal from the Russian Empire through armed insurrection with the aid of Germany.

The third period, "post-activism", covers the early years of Finnish independence. The aim of all the activities of the nationalist "white camp" was to act against a possible expansion of Soviet Russia, as well as to give assistance to the people related to Finns in Soviet Karelia and counter leftist revolutionaries. This period of the "white activism" is also closely related to the so-called "Wars for kindred peoples"1, which can be regarded as a prologue to the offensive of right-wing forces in Finland in 1920s-1940s. Namely, later from these "Kindship Wars" emerged the problem of Karelian refugees in Finland [Nygård 1978, pp. 125-128], which defined the initial activities of the extreme right. At the same time, the factor of "hatred of everything Russian" also acquired a new dimension.

Evaluation of the overall role and importance of the Academic Karelia Society, the Lapua Movement and the party Patriotic People's Movement in Finnish society is an ambiguous problem. Based on the fact that all three organisations were forbidden - the Lapua Movement in 1932, AKS and IKL in 1944 [Perälä 1998, pp. 282-287; Uola 1999, p. 36], it would be valid to assume that the result of their work was insignificant. Especially because, based on the Article 20 of the Armistice Agreement signed between Finland and the USSR in Moscow on 19 September 1944, the so-called "articles about discrimination", Finnish communists, the main opponents of the extreme right, were released from prisons and camps and received a further full freedom of action [The Foreign Policy of the Soviet Union During the World War II... pp. 178-179]. Thus, the defeat of right-wing nationalists in 1944 appears to be full.

However, judging by some of the circumstances, this view would be unacceptably limited in fact.

First of all, it should be borne in mind that the very emergence of the Academic Karelia Society was a consequence of the political frustration of society with the results of the process of becoming an independent Finnish state. It is clearly found primarily affecting much of the Finnish society. Heirs of the "Fennoman movement" had to give up on the then existing political parties and societies. The Civil War, the Tartu Peace Treaty and

${ }^{1}$ In Finnish history the ideology of "Greater Finland" is closely related to the so-called "Wars for kindred peoples". The plans of "white" activists of the "Kindship Wars", which in Finnish received the sumptuous name of "tribal wars", played the most important role. The aim of these campaigns was to create a "Greater Finland". In other words, they were an attempt to attach the Soviet Karelia to Finland in years 1918-1922. Although the initiator of the "Kindship Wars" were private individuals, volunteers, the Parliament and the Government of Finland gave them such a large-scale support that researcher Jouko Vahtola, who is the foremost expert of this topic in Finland, called them even a "Finnish military campaign in Russia" [Vahtola 1997, p. 13]. 
the "Kindship Wars" led to a clearly unsatisfactory outcome from the perspective of the "white activists".

The right nationalist movement of the early 1920's had a strong foreign policy orientation. It strengthened the idea of incorporating all the kindship of the Finnish peoples. The question of Eastern and White Sea Karelia had an especially important place in these plans. The "Karelian interest" had become extremely popular, especially in university circles. Students represented the former participants of the Civil War, jaegers, and other members of the "white camp" who were dissatisfied with the outcome of the war. At the beginning of the 1920's Finland's foreign policy had uncertain prospects. The defeat of the armed uprising in the Soviet Karelia and the passive attitude of the Finnish Government to these events reinforced the distrust of students to the official authorities.

If it is easier to judge the significance of Lapua movement, building on its immediate results, the impact of AKS was especially noticeable in the postwar period. As Risto Alapuro stated, to the 1970's AKS influenced primarily on the cultural life of Finland [Alapuro 1973, p. 179]. In 1968, of nine bishops of the Lutheran Church of Finland, seven were former members of the Academic Karelia Society. Of the two remaining, one was a native Swedish speaker and thus, in principle could not even be a member of AKS. By 1966, 41 former members of AKS had the rank of a senior officer in the Finnish army. Further, one of the chairmen of the society Yrjö Vuorijoki cited the following data on former members of society: 5 rectors of universities and other higher education institutions; 104 professors; 4 mining councillors; 8 general directors, the President of the Supreme Administrative Court, 24 other senior government officials, and others [Notes of Yrjö Vuorijoki]. Even the President of Finland in 1956-1981, Urho Kaleva Kekkonen, was once a member of the AKS. Thus, the value of the Academic Karelia Society can not be overestimated. It is believed that this organisation, which has never aspired to be for the masses, and paved the way for a "revolution from within", to some extent, achieved its goal.

Throughout the 1920's the distinction between the "Red" and the "Whites" was preserved. The right wing emphasised the importance of preserving the heritage of the victory in the Civil War. They believed that the main threat to the independence of Finland was the expansion of the East. The bourgeoisie worried about the strengthening of the trade union movement, and especially its left character. Analysis of the results of the Civil War and the struggle for an acceptable form of government led to discontent right government. A typical phenomenon for the development of Finnish internal politics in the 1920's were frequent changes of governments [Perälä 1998, p. 25]. It was usually a formation of a cabinet of a parliamentary minority. The fragility of governments and discord in the political parties rekindled the ideal of a strong governmental power. Therefore, there developed an anti-communist nationalistic front led by the Lapua Movement.

It is obvious that the distinctive features of AKS, the Lapua Movement and IKL are also clearly visible in the differences of their role in society. As mentioned above, the impact of AKS was high mostly after its dissolution. The Lapua Movement, on the contrary, was a powerful non-political lobby, whose actions have contributed, in particular, to the adoption of the "anti-communist laws" of 1930 and affected Kyösti Kallio's government to resign in the same year and the appointment of the Prime Minister P. E. Svinhufvud for president in 1931 [Vasara 2008, p. 97]. The Lapua Movement organized numerous rallies demonstrating its power, and we can say that it was the most obvious manifestation of 
the organizations mentioned here. Fair to say that the Lapua Movement was a prominent and the most successful form of the Finnish right-wing radicalism of the interwar period. We can assume that the Lapua Movement also enjoyed influence in society after its dissolution, but not like AKS. The idea is that the negative example of the Lapua Movement's members influenced the fact that in the future, in the 1930's neither the left nor the rightwing extremism received a significant popularity among Finnish people.

IKL in the history of the Finnish parliamentary system was a unique phenomenon. This party is contradictory: on the one hand, it fought against the existence of the party system, on the other hand, since 1933, it had all the signs of a party, including its faction in parliament. If we evaluate IKL's importance as a party, it should be noted that in the elections, it never received mass support of the population, therefore, its role remained insignificant [Uola 1982, p. 146]. It makes more sense to look for the essence of the IKL in other areas of its operations. It seems to be important as a leading Finnish youth organization of the inter-war period, which was particularly closely linked to the academic youth of the country. It may be noted that the long-standing nationalist propaganda of the party to improve defence, the patriotic education of the younger generation benefited during the war, as many young members of the commanding staff had semi-militaristic training in adolescence.

IKL figures themselves frequently stressed the importance of the party to unite the people in the war years. Its opponents, especially after the war, ignored it, believing that the war itself rather unites people. Apparently, the researcher Mikko Uola was right, when he claimed that, due to the IKL activity, as well as the Lapua Movement in part, the Communist party of Finland remained underground during all of the 1930s [Uola 1982, p. 482]. To achieve unification of the people in times of war it was easier when the communists, in this regard, a destructive force, were not a public political party.

In general, the Academic Karelia Society, the Lapua Movement and the Patriotic People's Movement should be seen as pronounced nationalist attempts to defend the gains of the Civil War and continue to fight for the creation of "white activists" ideal state "Greater Finland". Their work was a continuation of the struggle for independence, which began with the activities of the "period of oppression", which created the Jaeger movement, spawned the Civil Guards and continued as a defence of "white Finland" after the Civil War in 1918.

In this respect, building on existing assessment information, it is still quite difficult to exploit the full range of factual material that would characterise the Finnish right nationalist radicalism of the interwar period. Moreover, the paradox of the current situation is that the main problem arising in working with archival material relating to the disclosure of the activities of AKS is the absence of the main documents relating to specific work of this society. The fact is that, in the early 1940s, the Archive of the Academic Karelia Society along with its central office was located in the New Student House in the heart of Helsinki [Yrjö Vuorijoen muistiinpanoja]. However, in September 1944, on the eve of the dissolution of the Society, its members destroyed the documents that at the time they considered insignificant. It was, for example, the current correspondence, publicized materials, handwritten essays and writings. These manuscripts were mainly related to the early stage of AKS's activity. At the same time, it was decided to remove identity cards and documents such as various protocols from the capital, along with the society's flag [Notes of Yrjö Vuorijoki], and they disappeared. 
Moreover, according to one version, the unburned portion of the archive was sent to South Ostrobothnia ${ }^{2}$ and there safely hid somewhere [Notes of Yrjö Vuorijoki]. According to another version, the rest of the archive was taken to the city of Lahti, where it was burned by the initiative of the society's secretary E. Haatala [Yrjö Vuorijoen muistiinpanoja]. Subsequently, the police managed to find out from all the huge congregation of sources only fragmentary conversations and unimportant financial documents. This material is now in the National Archives of Finland, in the Collection of the dissolved organisations. In addition, the are also documents as a part of the History of Finland in the 1920-1940s Foundation's Collection. There is also a collection of AKS and the personal materials of its chairman Elmo KaIla [Kansallisarkisto, Suomen 1920-1940-luvun historian säätiön arkisto, E. E. Kailan kokoelma] In this section you can find a collection of the so-called "Club 22", which in 1958 was founded by former members of the AKS [Kerho 22] ${ }^{4}$.

In this respect, of course, in spite of the absence of the meetings protocols and decisions of the Academic Karelia Society, the National Archives collection is very valuable and has not been studied enough. Besides this further in-depth study of their valuable documents that are stored back in the University of Helsinki (at the National Library of Finland) is now being awaited. At the beginning of the 1970s they began to collect materials on the history of the Academic Karelia Society. At the same time materials about AKS, the Security Police of Finland, the Military Archive and the Finnish Literature Society were transferred to the library [Notes of Yrjö Vuorijoki].

Many documents of the society are also included in the private collection of Professor Eino Leskinen, including the files of Bobi Siven [E. Leskisen kokoelma] ${ }^{5}$. That is, materials that are in the manuscript collection of the National Library of Finland, have different origins. Some of them were clearly part of the AKS's own archive. Among the materials are both original sources and their copies. Just a collection of AKS at the National Library includes 63 archival boxes. It was last supplemented in January 2008 [Yrjö Vuorijoen muistiinpanoja].

${ }^{2}$ It was this province on the West coast of the country that was the center of support for extreme right-wing nationalists.

3 Currently, the "Club 22" operates under the name "The Traditional Society of AKS". Its main purpose is to preserve the heritage of AKS.

${ }^{4}$ It should be noted that other versions of the fate of AKS archival documents appeared in the 19601970s, but it is hard to say exactly what really happened with this material after the autumn of 1944 . The author of the book Fatherland in Danger. AKS's Work on National Defense in 1922-1939 Kullervo Leinonen says in the preface to his work, that in the early 1980s representatives of the "Club 22" suggested that he write a thesis as a "correct" history of the Academic Karelia Society. Although the material of the National Archives on the history of the society were still unlisted, by the resolution of the "Club" K. Leinonen was given complete freedom to use data sources. However, the collection on the history of AKS appeared for the researcher too fragmented and it lacked structure, so after a few years he abandoned the project [Leinonen 2013, p. 4].

5 Between Finland and Soviet Russia the Tartu Peace Treaty was signed on 14 October 1920. It defined the new Finnish-Soviet border. According to the agreement, Finland received Petsamo, which guaranteed access to the Arctic Ocean, but in exchange Finland had to return Reboly and Porajärvi parishes captured in 1918-1919. On 21 January 1921, the alderman of Reboly parish, "white" activist Håkan Hans Christian (Bobi) Sivén, committed suicide as a protest. In an open letter to the Minister for Foreign Affairs of Finland Rudolf Holsti he explained his decision: "[...] I hope that my action will correct the error in the Karelian interest of Finland and inspire the Karelians in the future [ ... ] together with its fraternal people to fight for freedom". Bobby was the "ideal" martyr for the "Karelian interest", which had a very important place in the ideology of the Finnish extreme right of the interwar period. Subsequently, the AKS created the cult of his name [Vasara 2010, pp. 526-527]. 
In the manuscript fund are also collections of AKS and its leaders Vilho Helanen and Vilho Annala. Moreover, comparing the collection of AKS in the National Archives and in the Manuscript Library of the University of Helsinki it can be seen that, although the manuscript collection has much less material, it covers matters about which nothing in the National Archives has any details.

With regard the Lapua Movement, it should be noted that the problem of studying this movement is that, with rare exceptions, their practices were not documented. In particular, most protocols of its meetings with the adopted regulations do not exist. On the illegal activities of the movement, there are only reports of trials [Lapuan liikkeen oikeidenkäyntipöytäkirjat], but there are no documents of the members themselves. Leaders, as well as all the representatives of this movement, in its absolute majority refused to leave any documentary traces of their activities. It is believed that they acted in this way because they were afraid of such information becoming public. This would be obviously highly undesirable for them. In addition, it should be noted that in the original motion there did not even exist the official documentary fixed program.

Nevertheless, despite the fact that the activities of the Lapua movement were largely clandestine and suspicious in the sense of the rule of law, many of the most important primary sources are now committed publicly and "legal" [Siltala 2005, p. 21]. Though the movement has left very little documentation about its work, from a newspaper polemic, performances at court sessions, private and official correspondence it is possible to draw conclusions, how members of the movement saw themselves against the background of their fellow nationalists and what they feared [Siltala 2005, p. 23]. In this respect, we can assume that the most complete material for the study of the history of the Lapua Movement still is in the National Archives of Finland in the Collection of The History of Finland from the $1920 \mathrm{~s}-1940 \mathrm{~s}^{6}$. It is quite revealing that when, finally, the history of IKL in the early 1980's was written, due to inflation the funds practically melted [Uola 1999, p. 25] ${ }^{7}$.

It is easy to assume that documents of the police authorities would also be a valuable help for the study of the history of Lapua Movement. However, they are not. Archival documents of the Central detective police can be divided into those that were created before and after the revolt in Mäntsälä [about the revolt: Siltala 2005, Vasara 2008]. Before the revolt, investigative police officers did not consider the Lapua Movement a main problem. Therefore, when receiving allegations of illegal actions of movement, they usually did not end up in the official reports. They were verbally passed to decision-makers, if ever passed on. Written documentation, especially confiscated lists and personal files of members of registered associations of the Lapua movement and IKL police officers were

6 The fund was founded in 1953 on the basis of materials of the liquidated public company "Shop IKL" (October 1944) and the IKL's restaurant "Black Bear" (1955). The fund founders were former activists of the IKL Professor Bruno Salmiala and Vilho Annala, as well as the farmer Paavo Rautala. As the purpose of the fund, they aimed to promote and support research into the history of the 1920s-1940s, although, in fact, they had in mind first and foremost the history of the AKS and the IKL.

7 The Fund was established mainly during the 1950s [Uola 1982, p. 526]. Over time, the collection has become fully accessible, and its materials are constantly replenished. The structure of the Fund includes such private collections as the collection of activists Heljä Riipinen, Vilho Annala and Bruno Salmiala. In addition, there are kept newspaper clippings, and many documents relating to the kidnapping of the former president K. Ståhlberg, the revolt in Mäntsälä and the like. Separately, it should be noted that records of conversations with many veterans of the Lapua movement and IKL are stored in the archive. This material was collected by colonel Paavo Susitaival in the 1950s. Unfortunately, Susitaival sought in his work, first and foremost, to repel "the Lapua era" based on anecdotes rather than serious factual material. 
destroyed in the autumn of 1944. There remains only some of the materials of the police unit of Vyborg, as well as documents that are in other places were left untouched [Siltala 2005, p. 26].

As pointed out by the activist of the movement Artturi Vuorimaa, their office kept all received letters and telegrams, and even records of all phone messages and answers to them [Siltala 2005, p. 27]. This has been mentioned also in the records of U.K. Kekkonen, who was a member of the Commission of Inquiry. The archive of the Lapua Movement was confiscated after the revolt in Mäntsälä in 1932 [Kansallisarkisto, Lakkautettujen järjestöjen arkistot: Lapuan liike, Siltala 2005, pp. 26-27] However, these materials are not present in the archive of the Central Detective Police nor in the archive of Court Council of Turku, where the lawsuit against the revolt participants took place. Thus, it is hoped, on valid grounds, that the documents fell into the hands of private individuals. This is because, for example, a son of Matti Malkamäki, the Lapua delegation member reported that his father bought the archive at auction and put it in a warehouse at the station of Lapua. Boxes were saved from fire in 1937, but Malkamäki Sr. got back only one of them. After the war, he said that these priceless archival boxes belonged to different people [Siltala 2005, p. 27].

Thus, engaging with the history of the IKL, a researcher is clearly facing the same problems as in the case of the AKS. In the National Archives IKL'S documents are mainly stored with documents of the Lapua Movement. Starting from 1933, the IKL had its faction in the parliament, thus its materials are different in composition from the materials of the Lapua Movement. Unfortunately, all protocols of the IKL fraction after 1938 in the National Archives and the Archives of the Finnish Parliament are missing. The documents of the central offices and local offices of IKL have been destroyed. In addition, contributions received from party members that are stored in the archives are very modest in structure. Moreover, many of them were simply destroyed by the autumn of 1944. It should also be noted that all the documents of the National Archives related to right-wing nationalist organisations of the interwar period are not very logically organised, which complicates systematic study of the material.

In this respect, it is clear that in the absence of many archival materials of the Academic Karelia Society, the Lapua Movement and the Patriotic People's Movement, future studies of right-wing nationalist movements in Finland must make use of journalism, newspaper articles, circulars, and the like. This is the case not only for these organisations, but also other parties. In this respect, documents are stored in the archives of the Communist Party of Finland (The People's Archive), the Social Democrats, the Coalition Party (Archive of Bourgeois Work) and then Agrarian Union (Archive of the Centre Party and the Countryside) ${ }^{8}$. Especially neglected is the quite extensive collection of materials relating to right-wing radical movements in the Archive of President U. K. Kekkonen.

${ }^{8}$ Of these funds, in particular, we can find many of the questions related to nationalist organization finances. In addition, for example, in the archives of the Communist Party of Finland can be found mostly well preserved microfilm materials of the period from 1920 to 1945. From the actual party documents important are also programmatic manifestos, reports and other similar materials. This archive also kept a special collection of "Finnish fascism - the right organizations", where there are documents collected and systematized in the mid-1930s about the activities of the IKL by the Progressive Party. The value of this collection is that it highlights the activities of the Finnish extreme right-wing forces after 1944. The Archive of the Social Democratic Party of Finland is important because of the collection of materials about the elections in 1933 and 1936, stories of the party functionaries of the election campaign against the IKL. 
At the same time due to the absence of many archival materials that characterise the right-wing nationalist sentiments in Finland in the interwar period, it is still important to study journalism, which still has not been fully introduced in the scientific work. Moreover, it concerns not only the disclosure of the activities of these organisations, but also to the extent possibility, and the other parties. In particular, the publication of AKS, including magazine Suomen Heimo, published in 1923-1944 [Suomen Heimo] and designed for a wide range of readers, and the circular AKS (Circular of the Academic Karelia Society), only for the members of the society, have been used by us as a very important source.

Thus, the absence of official documents of the Lapua Movement can be compensated by journalistic materials. Here you can trace the activities of the Lapua Movement both during its lifetime and after its dissolution. Journalism considers that this movement can be used even as a description of the situation through the eyes of its coevals. The activities of the Lapua members usually did not leave their opponents indifferent. Thus, there are numerous publications of an extreme right and left character. The Lapua Movement also had its own newspaper organs, the foremost of which is Ajan Sana. We have also actively used the party newspaper of IKL, the direct heir of Ajan Sana, Ajan Suunta.

Finally, people still have not actively investigated the problem of studying the history of the dissolution of the extreme right-wing nationalist movements. The fact is, after the Moscow armistice in 1944, liquidators were appointed to dismantle the property of especially those organisations [Uola 1999, p. 222]. In September of 1944 many of the documents were destroyed for unknown reasons. In addition, the loss of reports and official correspondence of the liquidators on the AKS and the IKL remains as a mystery: how they at some point disappeared from the archives of the Ministry of Internal Affairs [Uola 1999, pp. 252-255].

Thus, considering the problem of studying the history of right-wing nationalist movements in Finland it can be argued that, along with the importance of this research to explain the policy of Finland 1920-1930s, as well as the problem of the country's participation in World War II on the side of Nazi Germany, there are still quite good prospects for the study proposed here. Moreover, it is possible to hope that researchers will mainly find answers to urgent questions in the materials of the Finnish archives.

\section{References}

Ahti M. Ryssänvihassa: Elmo Kaila 1888-1935: aktivistin, asevoimien harmaan eminenssin ja Akateemisen Karjala-seuran puheenjohtajan elämäkerta [Hating All Russian: Elmo Kaila 1888-1935. Biography of an Activist, Grey Eminence of the Armed Forces and Chairman of the Academic Karelia Society]. Porvoo; Helsinki; Juva, WSOY Publ., 1999, 525 p. (In Finnish)

Akateemisen Karjala-Seuran kokoelma [Collection of the Academic Karelia Society]. Kansalliskirjasto [National Library of Finland], Sign. 464, 000 l. (In Finnish, unpublished)

AKS: $n$ Perinneyhdistys Ry [The Tradition Society of the AKS] (in Finnish). Available at: www.aksperinne.fi (accessed: 22.09. 2015).

Alapuro R.Akateeminen Karjala-seura: ylioppilasliike ja kansa 1920-ja 1930-luvuilla [The Academic Karelia Society: Student Movement and People in the 1920's and 1930's]. Porvoo; Helsinki, WSOY Publ, 197, 270 p. (In Finnish)

Baryshnikov V.N.Lapuaskoe dvizhenie i problema razvitiya sovetsko-finlyandskih otnoshenij v nachale 1930-h gg. [The Lapua Movement and the Problem of the Soviet-Finnish Relations in the early 1930 's.]. Mezhdunarodnaya nauchno-prakticheskaya konferenciya «Mezhdunarodnye otnosheniya na 
Severe Evropy: tradicii i sovremennost'» [International Relations in the North of Europe: Traditions and Modernity]. Petrozavodsk, Petrozavodsk State University Press, 2000, 325 p. (In Russian)

Baryshnikov V.N. Ot prohladnogo mira k zimnej vojne: Vostochnaya politika Finlyandii v 1930-e gody [From the Cold Peace to the Winter War: Finland's Eastern Policy in 1930's]. St. Petersburg, State University Press, 1997, 353 p. (In Russian)

E.E. Kailan kokoelma [Collection of E.E. Kaila]. Suomen Kansalliskirjasto [National Library of Finland]. The Manuscript Collection, Sign. 464. (In Finnish, unpublished)

Eino Leskisen kokoelma [Collection of Eino Leskinen]. Kansalliskirjasto [National Library of Finland], Sign.270, 000 l. (In Finnish, unpublished)

Eskelinen H. Me tahdoimme suureksi Suomenmaan: Akateemisen Karjala-Seuran historia. 1, Tausta, organisaatio, aatteet ja asema yhteiskunnassa 1922-1939 [Greatness of Finland Was Our Aim: History of the Academic Karelia Society 1. Background, Organisation, Ideas and Status in Society 1922-1939]. Helsinki, WSOY Publ., 2004, 401 p. (In Finnish)

Hyvämäki L. Sinistä ja mustaa: tutkielma Suomen oikeistoradikalismista [Blue and black: Study of the Finnish Right-Wing Radicalism]. Helsinki, Otava Publ., 1971, 282 p. (In Finnish)

Karemaa O. Vihollisia, vainoojia, syöpäläisiä: venäläisviha Suomessa 1917-1923 [Foes, Fiends and Vermin: Ethnic Hatred of Russians in Finland 1917-1923]. Helsinki, Publ. by Suomen historiallinen seura, 1998, 221 p. (In Finnish)

Kerho 22 [Collection of "Club 22"]. Kansallisarkisto [National Archive of Finland] (Helsinki). (In Finnish, unpublished)

Kirves J., Näre S.Luvattu maa: Suur-Suomen unelma ja unohdus [The Promised Land: the Dream and Oblivion of the Greater Finland]. Helsinki, Johnny Kniga Publ., 2014, 407 p. (In Finnish)

Lapuan liikkeen oikeidenkäyntipöytäkirjat [Trial records of the Lapua Movement]. Lakkautettujen järjestöjen arkistot [Collection of the Archive of the Forbiden Organizations]. (In Finnish, unpublished)

Leinonen K. Isänmaa vaarassa. AKS:n maanpuolustustyö 1922-1939 [Fatherland in Danger. AKS's Work on National Defense in 1922-1939]. Rovaniemi, Publ. by Pohjois-Suomen Historiallinen Yhdistys, 2013, 334 p. (In Finnish)

Mainio A. Terroristien pesä: Suomi ja taistelu Venäjästä 1918-1939 [Nest of Terrorists: Finland and a Struggle for Russia 1918-1939]. Helsinki, Siltala Publ., 2015, 379 p. (In Finnish)

Nygård T.Suomalainen äärioikeisto maailmansotien välillä: ideologiset juuret, järjestöllinen perusta ja toimintamuodot [The Finnish Extreme Right Between the World Wars: Ideological Roots, Organizational Basis and Forms of Activity]. Ed. by Jyvaskyla University. Jyvaskyla, Studia historica Jyväskyläensia Publ., 1982, 154 p. (In Finnish)

Nygård T. Suur-Suomi vai lähiheimolaisten auttaminen: aatteellinen heimotyö itsenäisessä Suomessa [Greater Finland or Helping the Kindred People: the Ideological Work in Independent Finland]. Helsinki, Otava Publ., 1978, 324 p. (In Finnish)

Paasivirta J.Suomen poliittisen työväenliikkeen kehitys [Development of the Finnish Political Labor Movement]. Porvoo, WSOY Publ., 1949, 95 p. (In Finnish)

Perälä R.Lapuan liike ja sanan mahti [The Lapua Movement and the Power of the Printed World]. Rovaniemi, Pohjois-Suomen historiallinen yhdistys Publ., 1998, 426 p. (In Finnish)

Rintala M. Three Generations: The Extreme Right Wing in Finnish Politics. Russian and East European Series, vol. XXII. Bloomington, Indiana University Press, 1962, 281 p.

Siltala J.Lapuan liike ja kyyditykset 1930 [The Lapua Movement and the Kidnappings of 1930]. Keuruu, Otavan kirjapaino Oy Publ., 2005, 704 p. (In Finnish)

Suomen työväenliikkeen historia [History of the Finnish Labor Movement]. Ed. by L. Haataja, S. Hentilä, J. Kalela, J.Turtola. Helsinki; Joensuu, Työväen sivistysliitto: Kansan voima Publ., 1976, 445 p. (In Finnish)

Uola M. Sinimusta veljeskunta. Isänmaallinen kansanliike 1932-1944 [The Blue-black Brotherhood. The Patriotic People's Movement 1932-1944]. Keuruu, Otava Publ., 1982. 551 p. (In Finnish)

Uola M. "Suomi sitoutuu hajoittamaan...” Järjestöjen lakkauttaminen vuoden 1944 välirauhan 21. artiklan perusteella ["Finland is Committed to Disperse ..." Abolition of the Organizations in 1944 Based on the Article 21 of the Armistice]. Vammala, Vammalan kirjapaino Oy. Publ., 1999, 288 p. (In Finnish)

Vahtola J. Nuorukaisten sota. Suomen sotaretki Aunukseen 1919 [War of the Young Men. Finnish Military Campaign to Olonets in 1919]. Helsinki, Otava Publ., 1997, 637 p. (In Finnish)

Vasara V.-T. Lapuaskoe dvizhenie (1929-1932) i putch v Myantsyale [The Lapua Movement (1929-1932) and the Mäntsälä Rebellion]. Trudy Kafedry istorii Novogo i novejshego vremeni Sankt-Peterburgskogo gosudarstvennogo universiteta [Transactions of the Chair of Modern and Current History]. No. 1. Ed. by B. P.Zaostrovcev. St. Peterburg, State University Press, 2008, pp. 91-104. (In Russian) 
Vasara V.-T. Nekotorye vzglyady na vopros o proiskhozhdenii nenavisti ko vsemu russkomu v Finlyandii [Some Views on the Question of the Origin of Hatred for Everything Russian in Finland]. Trudy Kafedry istorii Novogo i novejshego vremeni Sankt-Peterburgskogo gosudarstvennogo universiteta [Transactions of the Chair of Modern and Current History]. No. 4. Ed. by B.P.Zaostrovcev. St. Peterburg, OOO "AIK" Publ., 2010, pp. 244-256. (In Russian)

Vasara V.-T. O mifologizacii lichnosti: Bobi Siven v propagande finskih krajne pravyh sil v 19201930-e gg. [About Mythologizing a Person: Bobi Siven in Finnish Extreme Right-Wing Forces' propaganda in the 1920's and 1930's]. Lichnost' $v$ istorii $v$ ehpohu novogo i novejshego vremeni (pamyati professora S.I. Voroshilova): Materialy mezhdunarodnoj nauchnoj konferencii. S.-Peterburg, dekabr' 2009 [Personality in the history during the period of Modern and Contemporary history]. St. Peterburg, St. Peterburg State University Press, 2010, pp. 526-529. (In Russian)

Vneshnyaya politika Sovetskogo Soyuza v period Otechestvennoj vojny: Dokumenty i materialy. T. 2. Vneshnyaya politika Sovetskogo Soyuza v period Otechestvennoj vojny: 1 yanvarya - 31 dekabrya 1944 [The Foreign Policy of the Soviet Union During the World War II: Documents and Materials]. In 2 vols. Ed. by S. Majorov. Moscow, Gospolitizdat Publ., 1946, vol. 2, 2688 p. (In Russian)

Yrjö Vuorijoen muistiinpanoja [Notes Yrjö Vuorijoki] [Collection of AKS]. Kansalliskirjasto [National Library of Finland], MSign. 464 (In Finnish, unpublished) 